\title{
Venezuelan free-speech row goes nuclear
}

Freedom-of-speech groups have expressed concern at the treatment of a prominent Venezuelan physicist who has been fired as head of a government research lab after poking fun at the government over nuclear policy issues.

Claudio Mendoza was stripped of his position as head of a computational-physics lab in the Venezuelan Institute of Scientific Research (IVIC) in Caracas because of comments he made in an article written to promote a science-related play. He sarcastically suggested that Venezuelans should not worry about their country's growing alliance with 'rogue' nuclear states such as Iran, because Venezuelan officials do not listen to experts and so would not be able to develop nuclear technology anyway.

Although Mendoza is still a researcher in the lab, his dismissal as head after 10 years raises fears that his right to free speech has been infringed, says Juan Carlos Gallardo, chair of the American Physical Society's Committee on International Freedom of Scientists. The committee has written to Venezuelan officials to request details of

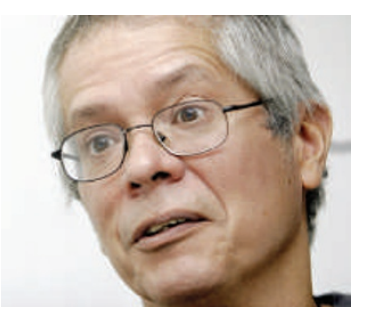

"I am just basically trying to survive as a researcher."

- Claudio Mendoza matter. Although Venezuela has no nuclear programme of its own, it has significant reserves of uranium ore, and in 2005 Venezuela announced that it would join forces with Iran to develop domestic nuclear power. Venezuela is also thought to have endorsed Iran's controversial uranium-enrichment programme, although without a seat on the UN Security Council, it was unable to influence the council's unanimous vote in December 2006 to ban the project.

Four days after the article was published, IVIC's board of directors removed Mendoza as lab head, and gave him 30 days to provide evidence of his apparent insinuation that Venezuela might be planning to enrich uranium. Mendoza submitted a dossier of newspaper articles but this was rejected as sufficient proof. When asked to retract his article, he refused.

The article was "the last drop" in a series of altercations in which Mendoza has criticized his paymasters, says IVIC director Máximo García Sucre. In 2003, for example, Mendoza complained that the governthe case. Although no other scientists there have reported similar harassment, the government has been accused of waging a campaign against freedom of speech in the media, and the fear is that similar repression is now extending to the research community. Gallardo has pledged to monitor the situation and take further action if Mendoza is sacked outright.

Mendoza says he has been accused of treason, even though his comments were meant to be witty and he was not writing in an official capacity. His remarks were published on 13 September 2006 in an article to publicize a production of Copenhagen by British playwright Michael Frayn. The play dramatizes a discussion between physicists Neils Bohr and Werner Heisenberg about the feasibility of developing nuclear weapons. Addressing fears that Venezuela might seek to join the nuclear club, Mendoza wrote: "Here bridges are built without engineers, diagnoses are made without doctors, oil is refined without petroleum experts, one can teach without being a teacher, you can govern without being a statesman. We will therefore explode nuclear energy while ignoring the physicists."

But it seems that nuclear policy is no joking ment was not giving enough financial support to IVIC - a claim denied by IVIC directors (see Nature 422, 257; 2003).

"He has manifest many times his nonconformity with IVIC decisions," García Sucre told Nature. "In a certain sense he is an activist. In this situation it is not possible to be head of a lab - there must be a minimum of affinity with scientific politics." He adds that such personnel changes are routine, and that Mendoza still has all the rights of any IVIC staff member.

Mendoza says that he is unsure whether he will be dismissed entirely. "I don't think I will try to get reinstated as head. I am just basically trying to survive as a researcher," he says.

"I hope he will understand that the measure that has been taken is a mild one," says García Sucre, adding that in making fun of government officials, Mendoza has indirectly criticized president Hugo Chávez. Asked whether Mendoza will be fired outright, García Sucre says: "He should start to work in his lab instead of being in the newspapers all the time saying he is being victimized. Then I don't see any problem."

Michael Hopkin

See Editorial, page 702. 